\title{
A review of the health and economic implications of patent protection, with a specific focus on Thailand
}

\author{
Inthira Yamabhai ${ }^{1,2^{*}}$ and Richard D Smith ${ }^{2}$
}

\begin{abstract}
Background: Although it has been two decades since the Thai Patent Act was amended to comply with the Agreement on Trade-Related Aspects of Intellectual Property Rights (TRIPS), there has been little emphasis given to assessing the implications of this amendment. The purpose of this review is to summarize the health and economic impact of patent protection, with a focus on the experience of Thailand.
\end{abstract}

Methods: A review of national and international empirical evidence on the health and economic implications of patents from 1980 to 2009 was undertaken.

Results: The findings illustrate the role of patent protection in four areas: price, present access, future access, and international trade and investment. Forty-three empirical studies were found, three of which were from Thai databases. Patenting does increase price, although the size of effect differs according to the methodology and country. Although weakening patent rights could increase present access, evidence suggests that strengthening patenting may benefit future access; although this is based on complex assumptions and estimations. Moreover, while patent protection appears to have a positive impact on trade flow, the implication for foreign direct investment $(\mathrm{FDI})$ is equivocal.

Conclusions: Empirical studies in Thailand, and other similar countries, are rare, compromising the robustness and generalizability of conclusions. However, evidence does suggest that patenting presents a significant inter-temporal challenge in balancing aspects of current versus future access to technologies. This underlines the urgent need to prioritize health research resources to assess the wider implications of patent protection.

\section{Introduction}

Access to information that is generated through research and development (R\&D) is a public good [1]. Because it is impossible to exclude people from using it, a price that reflects the actual cost of production cannot be charged. To address this, patents present a legal system that provides short-term exclusivity (or monopoly rights) over the production and sale of a specific product resulting from R\&D. This allows the firm to sell at a price higher than would otherwise be the case, compensating the costs of R\&D. However, there is some concern that the patent price is used to achieve 'super-normal' profits

\footnotetext{
* Correspondence: inthira.y@hitap.net

'Health Intervention and Technology Assessment Program (HITAP), Ministry of Public Health, Nonthaburi, Thailand

${ }^{2}$ Department of Global Health and Development, Faculty of Public Health \&

Policy, London School of Hygiene \& Tropical Medicine, London, UK
}

(profits in excess of those required to recoup R\&D costs) at the detriment of wider access to patented products [2].

The implications of patenting spread further, as innovation, technology, and knowledge development are crucial drivers of economic development and technology transfer resulting from international trade and investment. The topic of patenting has found its way onto the global agenda due to the World Trade Organization (WTO)'s Agreement on Trade-Related Aspects of Intellectual Property Rights (TRIPS), which expanded the Western tradition of patenting to all members of the WTO. Under this Agreement, patent protection must be available for at least 20 years, must be without discrimination against the place of invention or origin of product, and must apply to both products and processes [3].

This has generated especially heated debate within the health community concerning the impact that patents

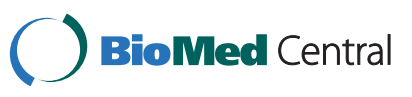


may have on the price of and access to medicines, affecting both availability and affordability. However, arguments concerning patenting tend to take one of two sides: that patenting should be continually strengthened to encourage greater trade and investment, or that patenting should be weakened to ensure that medicines are as cheap as possible in the belief that this will ensure the greatest access for those in need. There is seldom, if ever, consideration of both sides when informing policy makers how to strike a balance between affordable medicines, both now and in the future, and trade and investment. For instance, whilst continually strengthening patenting will likely lead to higher prices, thus further reducing access, weakening patenting may stifle longterm access since pharmaceutical companies might be reluctant to introduce new medicines into the market, and foreign investors may look to invest in other countries where there is better protection of their products. In order to determine the appropriate balance in policy (such as the use of TRIPS-flexibilities), it is important to establish: (i) the impact that patent protection has on price; (ii) the impact that price has on current and future access; and (iii) the impact that patents have on innovation in national and international settings. This paper addresses these issues through a review of the literature concerning these areas, with a specific focus on Thailand.

\section{Patenting and Thailand}

Thailand is a lower-middle-income economy with a 2007 per capita Gross National Income of US\$3,400 and a total population of 63.3 million [4]. Health services are provided by both public and private insurance schemes, with public insurance schemes covering $97 \%$ of the population. In $2007,72 \%$ of national health expenditure was financed by public expenditure [5]. The prices of medicines in Thailand are set mainly by market competition, with no policy related to price regulation [6]. In 1979, Thailand's Patent Act (B.E.2522) established the first legal protection for inventions in the country, although only process patents for pharmaceuticals were originally covered. This Act was revised in 1992 to introduce product patent protection for pharmaceutical products (13 years ahead of TRIPS compulsory compliance) [7].

The justification to amend the Thai patent law was to interest multinational companies to invest in Thailand. The other expected benefit of restricted patent protection in medicines is that this could increase domestic capability and strengthen the local pharmaceutical industry by the transfer of new technologies into the country [8], as the aim of a patent is to encourage technology transfer. Although technology diffusion can take place through a variety of channels that involve the transmission of ideas and new technologies-such as the imports of high-technology products, adoption of foreign technology and acquisition of human capital through various means-Foreign Direct Investment (FDI) was claimed as the most important channel for technology transfer $[9,10]$.

This revision coincided with the rise of HIV/AIDS as a major health problem together with concern over the rising costs of anti-retrovirals (ARV). For instance, $200 \mathrm{mg}$ (100 capsules) of original efavirenz sold in 2006 at 3,192 baht per bottle, while a generic equivalent was available at 1,292 baht [11]. A similar concern was expressed over other new medicines, which were not covered by the National Health Insurance system due to their high price [12]. The Sub-committee on selecting essential medicines under the National Health Insurance schemes therefore proposed compulsory licensing for seven patented medicines during 2006-2008 [13].

There were reactions from pharmaceutical companies. For instance, Abbott Laboratories withdrew its registration application for 10 new medicines in protest of the government use license on its product. These reactions were not confined to the pharmaceutical industry. In 2007 the Office of the United States Trade Representative elevated Thailand's ranking from the Watch List to the Priority Watch List, indicating concerns over deficiencies in Intellectual Property Rights (IPR) protection and enforcement [14], and announcing that privileges under the Generalized System of Preferences would be removed for three Thai products: gold accessories jewellery, polyethylene terephthalate, and flat screen television sets [15].

From the experience of pharmaceutical patent protection and associated policies during 1992-2008, it is apparent that patent protection has both health and economic consequences. A conceptual framework illustrating the broad implications of patent protection is illustrated in Figure 1. Patent protection affects the price of pharmaceuticals whereby price is a component in determining affordability and therefore access to existing medicines and industry investment in introducing or developing new medicines. A higher price would hinder access, but stimulate the development of new medicines through a higher R\&D budget enabling patients to benefit from access to new medicines in the future. Patent protection is also accompanied by foreign investment in domestic facilities for the production of pharmaceuticals. Finally, as indicated above, there are wider trade relationships that may be affected by patent decisions, and which are not related to medicines at all.

\section{Methods}

To ensure a manageable review, inclusion criteria covered the study scope and the type of study. 


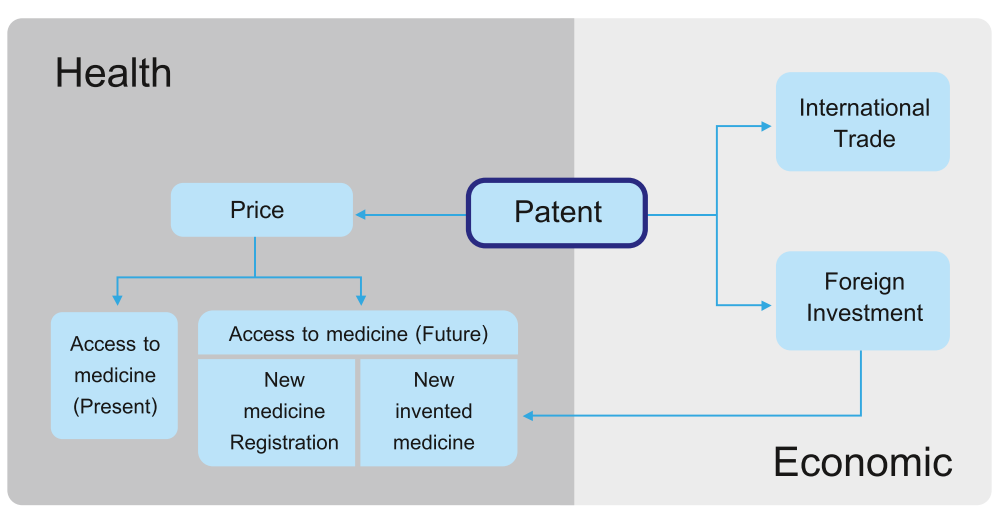

Figure 1 Conceptual framework of the implications of patenting on health and economic.

\section{Study scope}

Studies which assessed the implications resulting from patent protection for pharmaceutical products and/or processes, especially:

- the benefit and cost of patent protection for the pharmaceutical industry

- the interplay between patents and the affordability and availability of medicines

- the relationship between patents and new drug development

- the implications of patent protection on the wider economy, i.e. trade or foreign direct investment.

\section{Types of studies}

- Thai or English publications

- Research affecting any country

- Research articles, working papers or reports

- Research based on quantitative data (direct observation or experiment)

The databases searched covered both health and economic literature: Pubmed, Embase, Global health, International Bibiography of Social Sciences (IBSS), ABI/ INFORM, and Econlit. The selected Thai databases were the Health System Research Institute database, Journal of Health Science, Thai thesis database, The Thailand Research Fund, Thai Journal Citation Index Center, and the Research Library of the National Research Council of Thailand. Given the specific case study setting of Thailand, the review of Thai literature also included unpublished (grey) literature such as research reports, Master's dissertations, or Ph.D. theses. The dates of the published studies (1980-2009) were set so as to ensure the inclusion of all work conducted when the requirement of global standard patent protection was needed as, since the 1980s, intellectual property has became an important business tool, and new internationally-agreed trade rules for intellectual property rights were seen as a way to cope with the international economic tension [16].

The keywords employed in search queries covered five areas of interest: (i) patent policy, (ii) health, (iii) price, (iv) access, and (v) economy. In each area, the related keywords are identified in Table 1.

\section{Results}

Initial searches resulted in 4,012 abstracts, of which 61 were from Thai databases. Of these, 43 passed the inclusion criteria, including only three from the Thai databases. Papers were categorised into: (i) role of patent on price, (ii) role of patented price on present access, (iii) role of patented price on future access, and (iv) role of patent on international trade and investment. Tables 2 , $3,4,5$, and 6 provide a brief summary of these empirical studies.

\section{Role of patent on price}

Twelve studies, including two Thai studies, looked at the effect of patents on price. Most of these studies focused on the patent expiration effect in the USA. Patent protection appears to increase price by around 26\%-277\% depending on which of the three estimation approaches is used.

\section{Table 1 Keywords related to a research area}

\begin{tabular}{ll}
\hline Areas & Keywords \\
\hline Patent policy & $\begin{array}{l}\text { Intellectual property rights, Patent protection, Patent } \\
\text { TRIPS, TRIPS Plus, TRIP flexibility, Free trade agreement } \\
\text { Trade agreement }\end{array}$ \\
Health & Public Health, Health, Drug, Pharmaceutical, Medicine \\
Price & Price, Budget, Profit, Revenue \\
Access & Access, Afford/Affordability, Available/Availability \\
Innovation & Innovation, Research and development/R\&D, Incentive \\
& New molecular entity, Invention \\
Economic growth Investment, Trade/International Trade, Foreign direct \\
investment/FDI, Economic growth
\end{tabular}


Table 2 Empirical studies of the implications of patenting on price

\begin{tabular}{|c|c|c|c|c|c|}
\hline Authors/ Ref. no. & Period & Setting (Country/medicines) & Objectives & Model & Method \\
\hline Watal (2000)/[17] & 1985-1992 & $\begin{array}{l}\text { India, } 22 \text { patentable medicines } \\
\text { in mailbox (varied in wide } \\
\text { therapeutic areas) }\end{array}$ & $\begin{array}{l}\text { The effect of product patents, } \\
\text { price control and compulsory } \\
\text { licensing on medicine prices } \\
\text { and welfare. }\end{array}$ & $\begin{array}{l}\text { Demand function } \\
\text { estimation }\end{array}$ & $\begin{array}{l}\text { Comparing effects from } \\
\text { different demand functions- } \\
\text { the constant elasticity demand } \\
\text { and the linear demand } \\
\text { function-and estimating price } \\
\text { as a composite of the demand } \\
\text { function. }\end{array}$ \\
\hline Fink $(2000) /[18]$ & 1992 & $\begin{array}{l}\text { India, two therapeutic groups: } \\
\text { quinolones and synthetic } \\
\text { hypotensives }\end{array}$ & $\begin{array}{l}\text { The impact of product patents } \\
\text { on medicine price and } \\
\text { pharmaceutical company's profit }\end{array}$ & $\begin{array}{l}\text { Demand function } \\
\text { estimation }\end{array}$ & $\begin{array}{l}\text { Modeling a demand function } \\
\text { as a two-stage decision-making } \\
\text { process (chemical entity and } \\
\text { brands under that chemical } \\
\text { entity). Then estimating price } \\
\text { and profit under each substitution } \\
\text { elasticity among chemical entities } \\
\text { and among brands. }\end{array}$ \\
\hline Boersma et.al. (2005)/[19] & 1996 to 2001 & $\begin{array}{l}\text { The Netherlands, three medicines } \\
\text { whose patents expired between } \\
1996 \text { and } 2001\end{array}$ & $\begin{array}{l}\text { To observe price and share prior } \\
\text { to and after patent expiration }\end{array}$ & Observational study & $\begin{array}{l}\text { Trend analysis of volumes and } \\
\text { price (measured as defined daily } \\
\text { doses (DDD) prior to and after } \\
\text { patent expiries were calculated }\end{array}$ \\
\hline Suh et al. (2000)/[20] & 1984-1987 & $\begin{array}{l}\text { USA, } 35 \text { chemical entities whose } \\
\text { patents expired between } 1984 \\
\text { and } 1987\end{array}$ & $\begin{array}{l}\text { The effect of generic medicine } \\
\text { entry on price after patent } \\
\text { expiration }\end{array}$ & Regression analysis & $\begin{array}{l}\text { Collecting descriptive statistics } \\
\text { of price after patent expiration } \\
\text { and analysing the influential } \\
\text { factors affecting price, which } \\
\text { are number of multiple-source } \\
\text { medicines, market growth, } \\
\text { market size, profitability, severity } \\
\text { of illness, duration of treatment, } \\
\text { and number of years after } \\
\text { patent expiration. }\end{array}$ \\
\hline Magazzini et al. (2004)/[21] & $\begin{array}{l}\text { July 1987-December } 1998 \\
\text { (Quarterly data) }\end{array}$ & $\begin{array}{l}\text { USA, UK, Germany, and France, } \\
\text { all medicines whose patents } \\
\text { expired within the study period }\end{array}$ & $\begin{array}{l}\text { Price and determinant of price } \\
\text { after patent expiry }\end{array}$ & Regression analysis & $\begin{array}{l}\text { Collecting descriptive statistics } \\
\text { of prices before and after } \\
\text { patent expiration. Using regression } \\
\text { of the price with control of market } \\
\text { share of the patented products, } \\
\text { market size, \% of sales to the } \\
\text { hospital segment, the average } \\
\text { market growth, the number of } \\
\text { brand names, ratio of the average } \\
\text { price of original products, etc. }\end{array}$ \\
\hline Grabowski and Vernon (1992)/[22] & 1983-1986 & USA, 18 expired patent medicines & $\begin{array}{l}\text { The pricing and competitive } \\
\text { behaviour after patent expiration }\end{array}$ & Regression analysis & $\begin{array}{l}\text { Using descriptive statistics of } \\
\text { price index of the overall market, } \\
\text { original medicine, and generic } \\
\text { medicine. Using regression of } \\
\text { the determinant of generic entry. }\end{array}$ \\
\hline
\end{tabular}


Table 2 Empirical studies of the implications of patenting on price (Continued)

\begin{tabular}{|c|c|c|c|c|c|}
\hline Griliches and Cockburn (1994)/[23] & 1987-1990 & $\begin{array}{l}\text { USA, two anti-infective drugs: } \\
\text { cephalexin and cephradine }\end{array}$ & $\begin{array}{l}\text { The pricing and competitive } \\
\text { behaviour after patent expiration }\end{array}$ & Observational study & $\begin{array}{l}\text { Calculating the aggregate price } \\
\text { indexes for a simple two-goods } \\
\text { world where consumers buy } \\
\text { either the brand or the generic } \\
\text { version of a drug. }\end{array}$ \\
\hline Borrell (2007)/[26] & $1995-2000$ & $\begin{array}{l}14 \text { antiretroviral therapy medicines } \\
\text { in } 34 \text { low and middle income } \\
\text { countries. }\end{array}$ & $\begin{array}{l}\text { The impact of patents on medicine } \\
\text { prices across developing countries }\end{array}$ & Regression analysis & $\begin{array}{l}\text { Developing a price function as } \\
\text { a composite function of the } \\
\text { number of medicines in patent } \\
\text { and non-patent regimes, } \\
\text { number of generics after patent } \\
\text { expiration, number of doses } \\
\text { per day, efficacy, adverse } \\
\text { reactions, and number of years } \\
\text { in the US market. }\end{array}$ \\
\hline Supakankunti et. al. (1999)/[27] & 1987-1998 & $\begin{array}{l}\text { Thailand, six therapeutic categories } \\
\text { were chosen to represent the } \\
\text { patented market }\end{array}$ & $\begin{array}{l}\text { The effect of new patent law } \\
\text { on price }\end{array}$ & Observational study & $\begin{array}{l}\text { There were no patented } \\
\text { medicines so these medicines } \\
\text { were selected by other criteria. } \\
\text { Descriptive statistics were used } \\
\text { to report the price movement } \\
\text { or trend of the real price and } \\
\text { nominal price of branded and } \\
\text { generic medicines. }\end{array}$ \\
\hline Limpananont et. al. (2004)/[28] & 2001-2004 & $\begin{array}{l}\text { Thailand, antiretroviral therapy } \\
\text { medicines }\end{array}$ & $\begin{array}{l}\text { Price differences of patented and } \\
\text { generic medicines }\end{array}$ & Observational study & $\begin{array}{l}\text { Comparing and calculating } \\
\text { the price ratio of patented and } \\
\text { generic DDD prices }\end{array}$ \\
\hline Jones et al. (2001)/[29] & 1981-1994 & $\begin{array}{l}\text { Canada, } 82 \text { medicines from the } \\
\text { British Columbia Pharmacare } \\
\text { Programme. }\end{array}$ & $\begin{array}{l}\text { The impact of the Canadian } \\
\text { Patent Act in } 1987\end{array}$ & Regression analysis & $\begin{array}{l}\text { Using descriptive statistics of } \\
\text { prices before and after } 1987 \\
\text { and log regression of generic } \\
\text { market share, one factor, to } \\
\text { predict market price. }\end{array}$ \\
\hline Challu (1995)/' [30] & 1987- & Italy, 38 medicines & $\begin{array}{l}\text { The impact of the } 1978 \text { patent } \\
\text { law change }\end{array}$ & Observational study & $\begin{array}{l}\text { Comparing new drug prices in } \\
\text { Italy before and after the } 1978 \\
\text { patent law. Using US prices as } \\
\text { a reference. }\end{array}$ \\
\hline
\end{tabular}


Table 3 Empirical studies of the implications of patenting on present access

\begin{tabular}{|c|c|c|c|c|c|}
\hline $\begin{array}{l}\text { Authors/ } \\
\text { Ref. no. }\end{array}$ & Period & $\begin{array}{l}\text { Setting } \\
\text { (Country/medicines) }\end{array}$ & Objectives & Model & Method \\
\hline $\begin{array}{l}\text { Akaleephan et al. } \\
\text { (2009) [31] }\end{array}$ & $2000-2003$ & $\begin{array}{l}\text { Thailand, top } 70 \\
\text { imported medicines. }\end{array}$ & $\begin{array}{l}\text { The implications of the } \\
\text { TRIPS-Plus proposal, } \\
\text { and extension of patent } \\
\text { life on price and access }\end{array}$ & $\begin{array}{l}\text { Regression analysis } \\
\text { and Modelling }\end{array}$ & $\begin{array}{l}\text { It was assumed that the } \\
\text { first medicine patent } \\
\text { expired in 2003. Drug } \\
\text { consumption and budget } \\
\text { from using generic were } \\
\text { estimated. This cost was } \\
\text { then compared with } \\
\text { increased cost from patent } \\
\text { life extension. }\end{array}$ \\
\hline $\begin{array}{l}\text { Yamabhai et al. } \\
\text { (2009) [32] }\end{array}$ & $2006-2008$ & $\begin{array}{l}\text { Thailand, } 7 \text { government } \\
\text { use licensed medicines } \\
\text { in ARVs, heart disease } \\
\text { and anti-cancer }\end{array}$ & $\begin{array}{l}\text { The implications of } \\
\text { Thailand's government } \\
\text { use licenses on health } \\
\text { and trade and foreign } \\
\text { investment }\end{array}$ & $\begin{array}{l}\text { Regression analysis } \\
\text { and Markov model }\end{array}$ & $\begin{array}{l}\text { Estimating the increased } \\
\text { no. of patients with access } \\
\text { to government use license } \\
\text { medicines from the current } \\
\text { number of access and up to } \\
5 \text { years. The Markov model } \\
\text { was used to simulate the } \\
\text { heath impact. Trend analysis } \\
\text { of export and foreign } \\
\text { direct investment } \\
\text { was employed. }\end{array}$ \\
\hline Attaran (2004)/[33] & 2003 & $\begin{array}{l}65 \text { low and middle } \\
\text { income countries, } \\
319 \text { WHO essential } \\
\text { medicines }\end{array}$ & $\begin{array}{l}\text { How many medicines } \\
\text { are under patent in low } \\
\text { and middle income } \\
\text { countries? }\end{array}$ & Survey & $\begin{array}{l}\text { Surveying pharmaceutical } \\
\text { companies and their patent } \\
\text { agents to determine where } \\
\text { and how patentable } \\
\text { medicines in the essential } \\
\text { list of the WHO are now } \\
\text { patented in developing } \\
\text { countries }\end{array}$ \\
\hline Borrell (2003)/[34] & 1995-1999 & $\begin{array}{l}34 \text { low and middle } \\
\text { income countries, } \\
\text { HIV/AIDS medicines }\end{array}$ & $\begin{array}{l}\text { The impact of patent } \\
\text { rights on medicine sales: } \\
\text { reducing or increasing. }\end{array}$ & Modelling & $\begin{array}{l}\text { Developing two simultaneous } \\
\text { relationships: (1) the } \\
\text { relationship between the } \\
\text { likely entry decision across } \\
\text { drug-country-year triplets } \\
\text { and patents; and (2) } \\
\text { the relationship between } \\
\text { market coverage (i.e. mean } \\
\text { coverage of patients with a } \\
\text { specific ARV drug) and patents } \\
\text { conditional on drug entry } \\
\text { decisions and patent regime. }\end{array}$ \\
\hline
\end{tabular}

The first approach uses elasticity of demand to calculate price. This has been used to estimate the likely effects of patents on the price of medicines not currently under patent protection, and to extrapolate to a situation of those medicines being under TRIPS obligations. Using this methodology, Watal (2000) showed that all patentable medicine prices in India would increase by a mean of $26 \%$ with linear demand and $242 \%$ with

Table 4 Empirical studies of the implications of patenting on incentive to introduce medicine to market

\begin{tabular}{|c|c|c|c|c|c|}
\hline Authors//Ref.no. & Period & $\begin{array}{l}\text { Setting } \\
\text { (Country/medicines) }\end{array}$ & Objectives & Model & Method \\
\hline $\begin{array}{l}\text { Mansfield } \\
(1986) /[37]\end{array}$ & 1981-1983 & $\begin{array}{l}100 \text { U.S. manufacturing } \\
\text { firms from twelve } \\
\text { industries including the } \\
\text { pharmaceutical industry }\end{array}$ & $\begin{array}{l}\text { The effect of patent } \\
\text { protection on the rate of } \\
\text { development and } \\
\text { commercialization of } \\
\text { inventions. }\end{array}$ & Survey & $\begin{array}{l}\text { Surveying U.S. manufacturing firms in } \\
\text { order to know the proportion of its } \\
\text { inventions developed in 1981-83 that } \\
\text { would not have been developed and or } \\
\text { commercially introduced if it could } \\
\text { not have obtained a patent. }\end{array}$ \\
\hline $\begin{array}{l}\text { Lanjouw } \\
(2005) /[39]\end{array}$ & 1982-2002 & $\begin{array}{l}68 \text { countries at all income } \\
\text { levels and including all } \\
\text { medicine launches over } \\
\text { the period of study. }\end{array}$ & $\begin{array}{l}\text { How patent rights } \\
\text { and price regulation affect } \\
\text { whether new medicines are } \\
\text { marketed in a country, } \\
\text { and how quickly }\end{array}$ & Probit model & $\begin{array}{l}\text { Using probit models of the probability } \\
\text { that a new medicine is launched in a } \\
\text { given country within either two years or } \\
\text { ten years of the medicine's first } \\
\text { appearance in the global market and a } \\
\text { log-logistic hazard model of the time } \\
\text { path of country launches }\end{array}$ \\
\hline
\end{tabular}


Table 5 Empirical studies of the implications of patenting on incentive to invent new medicine

\begin{tabular}{|c|c|c|c|c|c|}
\hline Authors/Ref.no. & Period & $\begin{array}{l}\text { Setting } \\
\text { (Country/medicines) }\end{array}$ & Objectives & Model & Method \\
\hline $\begin{array}{l}\text { Grootendorst } \\
(2007) /[42]\end{array}$ & 1988-2002 & $\begin{array}{l}\text { Canada, prescription } \\
\text { medicine expenditure }\end{array}$ & $\begin{array}{l}\text { The implications of } \\
\text { patent policies (Bills C-22 } \\
\text { and C-91) on medicine } \\
\text { expenditure and on R\&D } \\
\text { activity }\end{array}$ & Modelling & $\begin{array}{l}\text { 1. Estimating the medicine expenditures } \\
\text { as a function of year dummies and lagged } \\
\text { public drug expenditures, while controlling } \\
\text { for a vector of other covariates that could } \\
\text { affect drug spending. 2.Estimating R\&D } \\
\text { expenditure whose patent policy changed } \\
\text { as an influenced factor }\end{array}$ \\
\hline $\begin{array}{l}\text { Hughes et al. } \\
(2002) /[43]\end{array}$ & 2001 & USA & $\begin{array}{l}\text { The effect of patent } \\
\text { termination on current } \\
\text { and future patients }\end{array}$ & Modelling & $\begin{array}{l}\text { From models developed by various scholars } \\
\text { during 1987-2002, five step models were } \\
\text { estimated:1) the effect of patent termination } \\
\text { on total revenue, 2) the effect of total revenue } \\
\text { on R\&D budget, 3) the effect of R\&D budget } \\
\text { on new medicine development, 4) the effect } \\
\text { of new medicine on life year and 5) life year } \\
\text { in monetary term }\end{array}$ \\
\hline $\begin{array}{l}\text { Giaccotto C. et al. } \\
(2005) /[44]\end{array}$ & 1980-2001 & USA & $\begin{array}{l}\text { The effect of price control } \\
\text { policy on number of new } \\
\text { drugs }\end{array}$ & Modelling & $\begin{array}{l}\text { Estimating the decreased R\&D budget as a } \\
\text { function of five main items (price, GDP, } \\
\text { foreign sales, dummy variables representing } \\
\text { the years for which the Kefauver-Harris } \\
\text { amendment and the Waxman-Hatch Act). } \\
\text { The value of forgone R\&D was then used } \\
\text { to calculate the number of forgone drugs } \\
\text { by dividing with } \$ 802 \text { million } \\
\text { (cost of R\&D per drug) }\end{array}$ \\
\hline $\begin{array}{l}\text { Colleen } \\
(2003) /[45]\end{array}$ & 1980-1990 & $\begin{array}{l}\text { USA, six compulsory } \\
\text { licensing }(\mathrm{CL}) \text { medicines }\end{array}$ & $\begin{array}{l}\text { The rate of innovation } \\
\text { activities of pharmaceutical } \\
\text { companies after } C L\end{array}$ & $\begin{array}{l}\text { Observational } \\
\text { study }\end{array}$ & $\begin{array}{l}\text { Observing the rate of patenting and other } \\
\text { measures of inventive activity five years } \\
\text { before and after } C L\end{array}$ \\
\hline
\end{tabular}

constant price elasticity of demand [17]. Similarly, by accounting for different products through trademarks and advertising, Fink (2004) used this approach to estimate that prices would increase by $30-277 \%$ if these medicines came under patent protection [18].

This approach would be useful if the price elasticity of demand is known and correct. For the pharmaceutical market, the consumption decision commonly involves participation by a physician and a third party payer (government or hospital committee). The consumer may or may not play some part in the price payment, depending on a country's specific regulatory and reimbursement regimes. The pharmaceutical market's demand function is thus often distorted, and a model based on price elasticity of demand might not present a real world situation of the complexity of the pharmaceutical market.

Second, the observation of price before and after patent expiration is used to infer the price effect of patent protection. Boersma et.al. (2005) illustrated that-when there is no patent protection-prices generally fall by $50-70 \%$ [19]. Suh et al. (2000) showed a decline to approximately $30 \%$ of the original price three years after patent expiration [20]. Also, Magazzini et al. (2004) showed that the price index decreased three years after patent expiration by approximately $20 \%$ in Germany and France while the UK price index was stable [21]. Conversely, two US studies by Grabowski and Vernon (1992) and Griliches and Cockburn (1994) showed that-following generic entry-an original product can have an increase in price of $7 \%$ and $11 \%$ after one year and two years respectively [22]. Another study showed a $60 \%$ price increase three years after expiration, while the generic price decreased by 30\% [23]. These increases may reflect increased advertising intensity once the market protection of patenting has expired.

However, the effect in each country will differ since each nation has a different health system in terms of medical tradition, policy for financing and supporting generic entry, and brand royalty of physicians, pharmacists and customers. The marketing strategy also differs among pharmaceutical companies, who often spend more heavily on the intensity of advertising once the patent has expired, which could explain at least some of the post-patent price increase. It appears that medicine prices, in general, depend on several supply and demand factors. For example, therapeutic advantage and number of substitutes are both significant price determinants; as the number of substitutes increased in one study from one to two, there was an average $38 \%$ decline in the ratio of the new drug price to the average existing market price [24]. Kanavos and Vandoros (2011) also found that product age has a significant and negative effect on prices [25].

Third, studies perform regression analysis of factors influencing medicine prices, of which patent is one such factor. Borrell (2007) estimated patent impact on price 
Table 6 Empirical studies of the implications of patenting on economic growth and/or foreign direct investment

\begin{tabular}{|c|c|c|c|c|c|}
\hline Authors/Ref. no. & Period & Setting & Objectives & Model & Method \\
\hline TDRI (2003)/[47] & 2003 & Thailand & $\begin{array}{l}\text { The impact of } \\
\text { Thai-US FTA on } \\
\text { export and import }\end{array}$ & $\begin{array}{l}\text { Computable General } \\
\text { Equilibrium (CGE) }\end{array}$ & $\begin{array}{l}\text { Estimating benefit from trade in } \\
\text { goods and the benefit to the } \\
\text { economy as a whole by matching } \\
\text { the industries that have higher } \\
\text { revealed comparative advantage } \\
\text { (RCA) index }\end{array}$ \\
\hline 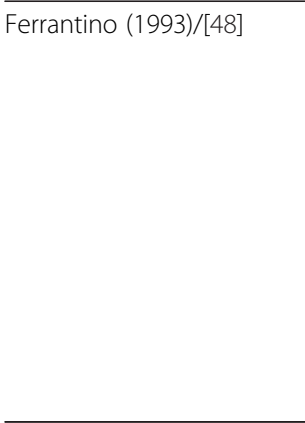 & 1982 & $\begin{array}{l}\text { U.S. firm, U.S. affiliated } \\
\text { in } 45 \text { countries }\end{array}$ & $\begin{array}{l}\text { The effect of IPR on } \\
\text { trade and investment } \\
\text { flows }\end{array}$ & Gravity model & $\begin{array}{l}\text { Using dummy (0/1) variables to } \\
\text { reflect differences in national IPR } \\
\text { protection schemes and control } \\
\text { for economic risk (distance, phone, } \\
\text { landlocked, colony and European } \\
\text { countries), political risk (Paris } \\
\text { Convention member, restriction } \\
\text { to foreign firm, number of } \\
\text { international memberships, } \\
\text { duration of patent), labour costs, } \\
\text { population and GDP, while } \\
\text { dependent variables are total } \\
\text { export, royalty fee, sales of affiliate }\end{array}$ \\
\hline $\begin{array}{l}\text { Markus and Penubarti } \\
(1995) /[49]\end{array}$ & 1984 & $\begin{array}{l}28 \text { manufacturing } \\
\text { sectors across } \\
77 \text { countries }\end{array}$ & $\begin{array}{l}\text { The effect of IPR } \\
\text { protection on } \\
\text { trade flows }\end{array}$ & Regression & $\begin{array}{l}\text { Using an empirical model in } \\
\text { which deviations of bilateral } \\
\text { sectoral imports from anticipated } \\
\text { levels are related to income, } \\
\text { trade barriers, and patent laws }\end{array}$ \\
\hline Braga and Fink (1999)/[53] & 1989 & $\begin{array}{l}89 \text { countries from } \\
\text { developed to least } \\
\text { developed countries }\end{array}$ & $\begin{array}{l}\text { The effects of increased } \\
\text { protection on } \\
\text { intellectual property }\end{array}$ & Gravity model & $\begin{array}{l}\text { Using a gravity model of bilateral } \\
\text { trade, foreign direct investment, } \\
\text { and technology licensing and } \\
\text { estimating the effects of increased } \\
\text { protection on a cross-section of } \\
89 \times 88 \text { countries. Using the index } \\
\text { on national IPRs systems } \\
\text { developed by Park and Ginarte } \\
\text { (1996). Estimating the effects of } \\
\text { explanatory variables (such as IPRs, } \\
\text { GDP and population of both } \\
\text { countries, geographical distance, a } \\
\text { common border, language) }\end{array}$ \\
\hline Pradhan (2007)/[51] & $1970-2000$ & India & $\begin{array}{l}\text { The effect of patent } \\
\text { protection on } \\
\text { pharmaceutical } \\
\text { exports }\end{array}$ & Gravity model & $\begin{array}{l}\text { Using a gravity model consisting } \\
\text { of GDP of the importing country, } \\
\text { distance, trading bloc dummy, } \\
\text { price and exchange rate }\end{array}$ \\
\hline
\end{tabular}


Table 6 Empirical studies of the implications of patenting on economic growth and/or foreign direct investment (Continued)

\begin{tabular}{|c|c|c|c|c|c|}
\hline Kondo (1995)/[52] & 1976-1980 & $\begin{array}{l}\text { U.S. outward } \\
\text { FDI in } 33 \\
\text { countries }\end{array}$ & $\begin{array}{l}\text { The effect of patent } \\
\text { protection on FDI }\end{array}$ & $\begin{array}{l}\text { Survey (for IPR index) and } \\
\text { Multiple regression of FDI } \\
\text { testing }\end{array}$ & $\begin{array}{l}\text { Developing their own patent } \\
\text { index including scope, patent life, } \\
\text { and provision from weighted } \\
\text { point survey firm. Then using } \\
\text { control factors of GDP per capita, } \\
\text { population, education, English } \\
\text { language, GATT member and } \\
\text { ICSID member. }\end{array}$ \\
\hline $\begin{array}{l}\text { Pfister and Deffain } \\
(2005) /[54]\end{array}$ & 1994-1995 & $\begin{array}{l}\text { The location choices of } \\
\text { French firms in } 17 \\
\text { developing countries }\end{array}$ & $\begin{array}{l}\text { The role of the patent } \\
\text { rights in the host country }\end{array}$ & $\begin{array}{l}\text { A conditional } \\
\text { logit model }\end{array}$ & $\begin{array}{l}\text { The independent variable is the } \\
\text { decision to invest in the countries. } \\
\text { The independent variables are } \\
\text { number of French competitors, } \\
\text { number of subsidiaries, openness, } \\
\text { GDP, GDP per capita, consumer } \\
\text { price index, status of EU union, } \\
\text { national R\&D investment over } \\
\text { GDP, education, democracy, } \\
\text { corruption, patent protection } \\
\text { index (Ginarte and Park index), } \\
\text { and dummy variable of the } \\
\text { exceeding patent protection } \\
\text { index. }\end{array}$ \\
\hline Fosfuri (2004)/[55] & $\begin{array}{l}\text { four time periods:1981-1983, } \\
\text { 1984-1987, 1988-1991, } \\
\text { 1992-1996. }\end{array}$ & $\begin{array}{l}75 \text { countries receiving } \\
\text { investments in chemical } \\
\text { plants during the period } \\
\text { 1981-1996 }\end{array}$ & $\begin{array}{l}\text { The impact of IPRs protection } \\
\text { compared with country risk } \\
\text { on the determinants of international } \\
\text { activity through wholly owned } \\
\text { operations, joint-ventures and } \\
\text { technology licensing, }\end{array}$ & $\begin{array}{l}\text { OLS, Tobit and GLS random } \\
\text { effect }\end{array}$ & $\begin{array}{l}\text { Independent variables are income } \\
\text { per capita, population, weighted } \\
\text { distance of country, averaged years } \\
\text { of schooling among the total } \\
\text { population, (exports + imports)/ } \\
\text { GDP, global index of risk, composite } \\
\text { index of risk (political, financial and } \\
\text { economic), dummy variables for } \\
\text { number of scientists and engineers } \\
\text { per million of population, time } \\
\text { fixed effect, and IPR index by } \\
\text { Ginarte and Park }\end{array}$ \\
\hline $\begin{array}{l}\text { Nunnenkamp and Spatz } \\
(2004) /[56]\end{array}$ & 1995 and 2000 & $\begin{array}{l}\text { U.S. FDI and US FDI in } \\
\text { industrial level in } 166 \\
\text { countries }\end{array}$ & $\begin{array}{l}\text { The relationship between IPR } \\
\text { protection and overall FDI and } \\
\text { by industry }\end{array}$ & Gravity model regression & $\begin{array}{l}\text { Finding FDI determinants through } \\
\text { a regression of FDI on GDP per } \\
\text { capita, population, distance to } \\
\text { U.S., the cost of living abroad, } \\
\text { average years of schooling and } \\
\text { IPRs index using Ginarte-Park for } \\
\text { the year } 1995 \text { and World Economic } \\
\text { Freedom (WEF) index for the year } \\
\text { 2000. Testing the industry } \\
\text { characteristics by adding industry } \\
\text { dummies in the previous } \\
\text { independent variable set. }\end{array}$ \\
\hline
\end{tabular}




\begin{tabular}{|c|c|c|c|c|c|}
\hline $\begin{array}{l}\text { Lee and Mansfield } \\
\text { (1996)/[57] }\end{array}$ & 1991 & $\begin{array}{l}\text { U.S. firms and investment } \\
\text { in } 14 \text { developingcountries }\end{array}$ & $\begin{array}{l}\text { The effect of IPR protection } \\
\text { level on U.S. firm's FDI and the } \\
\text { role of IPRs protection in chemical } \\
\text { industry }\end{array}$ & $\begin{array}{l}\text { 1. Survey for IPRs protection } \\
\text { perception 2. OLS regression } \\
\text { 3. Tobit model for chemical } \\
\text { industry }\end{array}$ & $\begin{array}{l}\text { Surveying perceived weakness of } \\
\text { IPR protection from } 94 \text { US firms } \\
\text { and developing two regression } \\
\text { models to find the influence of } \\
\text { IPR protection level for overall US } \\
\text { FDI and level of technology } \\
\text { transfer in the chemical industry. } \\
\text { For OLS of overall US FDI, } \\
\text { independent variables are } \\
\text { weakness of IPR, size of market, } \\
\text { with control for firm specific and } \\
\text { country specific, IPR index, market } \\
\text { size, dummy for Mexico, FDI in } \\
\text { previous year, degree of } \\
\text { industrialization, openness, and } \\
\text { time dummy variables. For Tobit } \\
\text { model from } 14 \text { US chemical } \\
\text { industries, the independent variables } \\
\text { are the percentage of firms that } \\
\text { felt weakness of IPR protection, GDP, } \\
\text { and dummy variables for firms, while } \\
\text { the dependent variable is the } \\
\text { percentage of firms that will invest } \\
\text { in facilities for sales and distribution. }\end{array}$ \\
\hline An et al. (2008)/[58] & $\begin{array}{l}1995 \text { (for FDI or licensing) } \\
\text { and } 1994 \text { (for exporting) }\end{array}$ & $\begin{array}{l}\text { U.S. FDI in } 52 \text { manufacturing } \\
\text { industries invested in } 62 \text { host } \\
\text { countries }\end{array}$ & $\begin{array}{l}\text { To examine the effect of } \\
\text { strengthening IPR protection } \\
\text { on the mode of technology } \\
\text { transfer: exporting, FDI or licensing }\end{array}$ & $\begin{array}{l}\text { A multinomial logit model } \\
\text { of three mode of entry } \\
\text { choices }\end{array}$ & $\begin{array}{l}\text { The explanatory variables covering } \\
\text { national characteristics, GDP, } \\
\text { absorptive capacity, distance, } \\
\text { cultural distance (English and index } \\
\text { developed by authors), FDI fixed } \\
\text { cost (economic freedom index), } \\
\text { market capitalisation and investment } \\
\text { cost index, and IPR index from } \\
\text { Ginarte and Park 1990. The industry } \\
\text { characteristics variables are industry } \\
\text { R\&D intensity and capital intensity } \\
\text { (the ratio of total real capital stock } \\
\text { to total industry sales). }\end{array}$ \\
\hline Maskus (1998)/[59] & 1989-1992 & U.S. FDI in 46 countries & $\begin{array}{l}\text { The effect of patent protection on U.S. } \\
\text { patent applications filed in host } \\
\text { country, total sales of foreign affiliates } \\
\text { of U.S. parents, U.S. exports shipped } \\
\text { to affiliates and total assets, foreign } \\
\text { affiliates of U.S. parents }\end{array}$ & $\begin{array}{l}\text { Seemingly Unrelated } \\
\text { Regression }\end{array}$ & $\begin{array}{l}\text { Estimating a simultaneous set of } \\
\text { equations to capture these joint } \\
\text { impacts, controlling for market size, } \\
\text { tariff protection, the level of local } \\
\text { R\&D by affiliates, distance from the } \\
\text { US, investment incentives } \\
\text { (proportion of affiliates receiving } \\
\text { tax concession numbers in host } \\
\text { country and in any of the countries) } \\
\text { and disincentives (proportion of } \\
\text { affiliates that employ a minimum } \\
\text { amount of local personnel no. in } \\
\text { host country and in any of the } \\
\text { countries. }\end{array}$ \\
\hline
\end{tabular}


Table 6 Empirical studies of the implications of patenting on economic growth and/or foreign direct investment (Continued)

\begin{tabular}{|c|c|c|c|c|c|}
\hline Javorcik (2004)/[60] & 1995 & $\begin{array}{l}\text { 1,405 global firms investing in } \\
\text { Eastern European countries }\end{array}$ & $\begin{array}{l}\text { The impact of intellectual property } \\
\text { protection on the volume of FDI }\end{array}$ & Survey and Probit model & $\begin{array}{l}\text { A questionnaire of decision to } \\
\text { invest in any country and mode } \\
\text { of entry was developed. Using a } \\
\text { Tobit regression of the decision } \\
\text { and mode of entry on GDP per } \\
\text { capita, population, corporate tax } \\
\text { rate, legal effectiveness, corruption, } \\
\text { privatization, openness, the overall } \\
\text { progress in reform, effectiveness of } \\
\text { the legal system, corruption level, } \\
\text { privatization policies and openness } \\
\text { to trade. For testing the mode of } \\
\text { entry, the author included firm } \\
\text { specific variables such as firm sales, } \\
\text { R\&D outlays as a percentage of } \\
\text { net sales, selling, general \& } \\
\text { administrative expenses as a } \\
\text { percentage of net sales, the number } \\
\text { of four-digit SIC codes describing a } \\
\text { firm's activities and a dummy } \\
\text { variable of each investor's regional } \\
\text { experience in the region before } 1989 \text {. }\end{array}$ \\
\hline Du et al. (2008)/[61] & 1993-2001 & $\begin{array}{l}6,288 \text { US firms investing in } \\
\text { various regions of China }\end{array}$ & $\begin{array}{l}\text { The impacts of four economic } \\
\text { institutions variables, including } \\
\text { property rights protection, the } \\
\text { degree of government intervention } \\
\text { in business operations, the degree of } \\
\text { government corruption and contract } \\
\text { enforcement, on the location choice } \\
\text { of foreign direct investment }\end{array}$ & Discrete choice model & $\begin{array}{l}\text { A survey was conducted of private } \\
\text { enterprises in China to create } \\
\text { three indexes which are the } \\
\text { degree of government intervention } \\
\text { in business operations, the degree } \\
\text { of government corruption, and } \\
\text { contract enforcement. The other } \\
\text { concerned variables are the } \\
\text { agglomeration, dummy for } \\
\text { presence of US Embassy or } \\
\text { Consulates and dummy for } \\
\text { government promotion policies, } \\
\text { wages, infrastructures (length of } \\
\text { highway per square kilometre in } \\
\text { a region), and education (percent } \\
\text { of higher education students } \\
\text { in the region). IPR index is the } \\
\text { logarithm of the patent per capita } \\
\text { approved number. }\end{array}$ \\
\hline
\end{tabular}


Table 6 Empirical studies of the implications of patenting on economic growth and/or foreign direct investment (Continued)

\begin{tabular}{|c|c|c|c|c|c|}
\hline Kawai (2009)/[62] & 1998-2006 & $\begin{array}{l}\text { 1,839 Japanese manufacturing } \\
\text { firms investing in China }\end{array}$ & $\begin{array}{l}\text { The determinants of Japanese } \\
\text { manufacturing firms' location } \\
\text { decisions in China }\end{array}$ & A conditional logit model & $\begin{array}{l}\text { Empirical models were developed } \\
\text { and tested. The dependent variable } \\
\text { is choice of investment }(1=\text { Yes, } \\
0=\text { No). The independent variables } \\
\text { are natural logarithms of the } \\
\text { number of Special Economic } \\
\text { Zones, IPRs index, natural logarithm } \\
\text { of the share of total investment in } \\
\text { fixed assets by state-owned units } \\
\text { in relation to total investment, GDP, } \\
\text { labour costs, road infrastructure } \\
\text { and natural logarithm number of } \\
\text { Japanese manufacturers All } \\
\text { explanatory variables are lagged by } \\
\text { one year. }\end{array}$ \\
\hline Seyoum $(2006) /[63]$ & 1990 and 1995 & 63 countries & The impact of patent protection FDI & The OLS regression & $\begin{array}{l}\text { Using the set of independent } \\
\text { variables which include patent } \\
\text { index by Ginarte and Park (1997) } \\
\text { and controlling other variables such } \\
\text { as market size, GDP growth, } \\
\text { exchange rates, population, } \\
\text { corruption, unemployment, trade/ } \\
\text { GDP, scientists and engineers, GDP } \\
\text { growth }\end{array}$ \\
\hline Lesser $(2002) /[64]$ & 1998 & FDI in 44 developing countries & $\begin{array}{l}\text { The effects of stronger IPR protection } \\
\text { in the areas of imports and Foreign } \\
\text { Direct Investment (FDI) }\end{array}$ & Multiple regression & $\begin{array}{l}\text { The variables includes income per } \\
\text { capita, past FDI, exchange rates, } \\
\text { tariffs, the proportion of previous } \\
\text { year FDI to GNP of pervious year, } \\
\text { and the degree of industrialization. } \\
\text { A new index was developed that } \\
\text { uses membership in international } \\
\text { treaties to measure the scope and } \\
\text { efficiency of IPR. }\end{array}$ \\
\hline $\begin{array}{l}\text { Park and Ginarte } \\
(1997) /[65]\end{array}$ & 1960-1990 & $\begin{array}{l}60 \text { countries from developed } \\
\text { to least developed countries }\end{array}$ & $\begin{array}{l}\text { The impact of IPR protection on } \\
\text { economic growth (GDP growth) }\end{array}$ & Regression & $\begin{array}{l}\text { Creating an IPR index and } \\
\text { estimating a system of equations } \\
\text { to identify the effect of IPR } \\
\text { protection and other national } \\
\text { characteristics on economic growth } \\
\text { such as R\&D activity, investment, } \\
\text { and education }\end{array}$ \\
\hline
\end{tabular}


Table 6 Empirical studies of the implications of patenting on economic growth and/or foreign direct investment (Continued)

\begin{tabular}{|c|c|c|c|c|c|}
\hline $\begin{array}{l}\text { Athukorala and Kohpaiboon } \\
(2006) /[66]\end{array}$ & $\begin{array}{l}\text { 1990-2001 (three-year } \\
\text { intervals) }\end{array}$ & $\begin{array}{l}168 \text { US-based MNEs that have } \\
\text { invested internationally } \\
\text { (42 countries) }\end{array}$ & $\begin{array}{l}\text { The determinants of the international } \\
\text { location of R\&D activity by foreign } \\
\text { affiliates of US-based MNEs }\end{array}$ & Regression analysis & $\begin{array}{l}\text { Included control variables are real } \\
\text { GDP, distance, percentage of } \\
\text { domestic sales in total affiliate } \\
\text { sale turnover, technology intensity } \\
\text { index, R\&D personnel per million } \\
\text { population, wages of technical } \\
\text { personnel, tax incentives for firm- } \\
\text { level R\&D activities, intellectual } \\
\text { property rights index (from World } \\
\text { Economic Forum, Global } \\
\text { Competitiveness Report), capital } \\
\text { stock of US firms, an index of } \\
\text { R\&D potential of output mix, } \\
\text { dummy variables for developing } \\
\text { countries other than NICs, newly } \\
\text { industrialized countries in East Asia, } \\
\text { financial crisis dummy, and vector } \\
\text { of time dummy variables }\end{array}$ \\
\hline Blyde and Acea (2003)/[67] & 1985, 1990 and 1995 & $\begin{array}{l}\text { The sources of FDI are } 19 \\
\text { OECD countries and } 40 \\
\text { countries as the recipients } \\
\text { of FDI, } 8 \text { of which are from } \\
\text { Latin America. }\end{array}$ & $\begin{array}{l}\text { The inflows of foreign direct investment } \\
\text { of Latin America and developing } \\
\text { countries after TRIPS }\end{array}$ & The gravity model & $\begin{array}{l}\text { The independent variables are GDP } \\
\text { per capita, population, dummy of } \\
\text { common language, past colonial } \\
\text { links and region, distance between } \\
\text { countries, Ginarte-Park IPR index }\end{array}$ \\
\hline $\begin{array}{l}\text { Supakankunti et al. } \\
(2001) /[70]\end{array}$ & 1988-1998 & Thailand & $\begin{array}{l}\text { The impact of patent law change in } \\
1992 \text { on FDI in Thailand }\end{array}$ & Observation & $\begin{array}{l}\text { Providing the trend of FDI for } \\
\text { industry in general and specifically } \\
\text { for the chemical industry in Thailand }\end{array}$ \\
\hline
\end{tabular}


in 14 ARV molecules in 34 low- and middle-income countries which have different patent regimes, where patent was eligible or ineligible between 1995 and mid2000. This showed that combination therapy containing at least one patented medicine is on average priced $70 \%$ higher than combination therapy containing only generic alternatives. Combination therapy containing at least one original medicine is priced 16\% higher than local copies even when it is introduced in to no-patent regimes [26].

In Thailand, the introduction of product patent protection in1992 seems to have had no effect on the price of patentable medicines that were in the market before 1992 [27]. Rather, the effect appears to concern only those patented medicines which were introduced subsequently. For example, one study compared the price of patented and generic HIV/AIDS medicines from 2001-4 and found that the patented price was approximately 1.5-3 times higher than the generic price in 2001 [28].

The experiences in Canada and Italy reflect the situation in Thailand. A study of the impact of the 1987 Canadian Patent Act, which extended the period of protection from seven to ten years while also allowing the generic industry to implement compulsory licensing, found that after 1987, medicine prices increased relative to pre-1987 prices [29]. Similarly, after a patent law in Italy came into effect in 1978, new medicine prices were $163 \%$ higher than new drug prices before 1978 [30].

\section{Role of patented price on present access}

Empirical evidence directly linking patented price and access is rare. Most studies describe how patenting increases prices (as above) and then assume that price affects access, but there is a lack of direct association between the extent of price increase and the extent of changes in access, controlling for other influence factors. As shown in Table 3, there were four studies found concerning this issue, two of which are in the Thai setting.

Akaleephan et al. (2009) examined the effect of patent life extension from a TRIPS-Plus proposal on access to medicines. They illustrated the drawbacks of extending the period of protection by showing that the availability of generics would help to save $105 \%$ of actual government expenditure, and accessibility would increase by $54 \%$ [31]. In addition, after compulsory license introduction in Thailand, the price of generic medicines was about $3-38 \%$ of their original price. As a result, there were approximately 8,000 extra patients utilizing EFV, and it is estimated that the increased number of patients with access to EFV will be 17,959 in five years [32].

Conversely, Attaran (2004) suggested that the main obstacles are associated with the country's socio-economic status, such as the lack of manufacturing capacity or poor health care systems [33]. His survey results show that only 17 from a total of 319 medicines on the WHO Essential Medicines List are protected by patents. In addition, Borrell and Watal (2003) showed that switching all medicines under a patent regime to a no patent regime globally would have increased the percentage of AIDS patients with access to new medicines from $0.88 \%$ to $1.18 \%$ [34]. However, with reference to individual countries, the findings suggested different magnitudes of impact. For example, in Thailand where most of the relevant medicines were under patent, it was estimated that around 10,000 additional prescriptions would be prescribed if all patents were waived, generating an increase in access of some $50 \%$.

\section{Role of patented price on future access Incentive to introduce medicine to market}

Pharmaceutical companies may refuse to market new medicines in response to weak national patent policy [35,36]. Mansfield (1986) estimated that $65 \%$ of products would not have been introduced if patent protection could not have been obtained [37]. While patents make local markets more attractive, multinationals may delay or avoid launching medicines in lower-priced countries because they are concerned about the implications for pricing in other markets [38]. For instance, Lanjouw (2005) determined the effects of patent policy and price control policy on market entry, and showed that extensive price control and process-only patent protection lowers the probability of having a new medicine in lower-income countries by $30 \%$ [39]. A brief summary of these two studies is shown in Table 4.

The model employed in these two studies was multicountry, from high-income to low-income countries. Although the results are more generalized, they sometimes mislead. Under some circumstances and model assumptions, patent protection has a positive effect for some countries, while under other circumstances it has a negative effect. Single country studies are particularly effective at maximizing their explanatory leverage by exploiting the availability of comparable units of analysis, whether over market or medicine characteristic variations within a country [40].

\section{Incentive to invent new medicine}

One implication of removing patent protection to gain increased current access is that this might result in patients foregoing the opportunity to receive a new medicine in the future, as it would not be discovered or developed [41]. There were four studies looking at this possibility, as shown in Table 5. Grootendorst (2007) illustrated that this clearly generates trade-offs between benefits now and in the future [42]. Indeed, heavily depending on assumptions, Hughes et al. (2002) estimated that for every dollar in consumer benefit realized from providing 
greater access to current medicines, future consumers would be harmed at a rate of three dollars in present value terms from reduced future innovation [43].

Giaccotto C. et al. (2005) investigated the role of price control on new medicine development, showing that price control policy in the USA during the 1980s resulted in forgone R\&D investment of US\$264-293 million, translating into 330-365 fewer new medicines, which is equal to one-third of all actual new medicines launched on the global market during that time period [44]. However, such studies lack a direct link between profitability and actual investment in $R \& D$. They illustrate the effect of patents on profit and assume that this translates directly into R\&D. Conversely, an observation of the innovation activities of pharmaceutical companies affected by compulsory licensing found that there was no uniform decline in the rate of medicine patenting and other measures of inventive activity by companies affected by compulsory licenses [45] Table 5.

\section{Role of patent protection on international trade and investment}

With respect to the broader impact, in a Free Trade Agreement (FTA) between Thailand and the US, one of the 23 negotiation issues was TRIPS-Plus, which requires a higher level of intellectual property protection than existed in the TRIPS agreement [46]. Five studies focusing on the impact of patents on trade were found. Based on a Computable General Equilibrium model, it was estimated that the FTA would increase the export and import levels of Thailand by $3.4 \%$ and $4.7 \%$, respectively [47]. This study also found, at the international level, that IPR protection had a positive influence on overall trade flows for both small and large developing economies [48-50]. These results are in line with other findings which show that patent protection had a positive impact on Indian pharmaceutical exports [51].

\section{Intellectual Property Protection and investment}

Nineteen studies, including one Thai study, looked at the effect of patents on FDI. Most of these studies used regression to analyze the effect of IPRs on FDI. Additional variables are included in the regression to control the differences in country specific factors. Their main similarity is in comparing IPR risk along with economic risk and/or political risk. Proxy indicators were used to represent economic or political risk. Most of these focused on the role of the national patent protection policy to attract US investors.

Six empirical studies found that patent rights protection does not influence the location choices of foreign investors. Some regression analyses of FDI in the 1980s based on research by Ferrantino (1993), Markus and Penubarti (1995), Kondo (1995), and Braga and Fink
(1999) found no significant link between IPR protection and FDI $[48,52,53]$. Using FDI data from the 1990s, the above results were again confirmed in the study of Pfister and Deffains (2005) who investigated the role of patent protection on the location choices of French firms investing in 17 developing countries [54]. In addition, the Fosfuri's (2004)'s study, which focused specifically on the chemical industry and accounted for the differences of country characteristics, did not find that IPR protection played a significant role in fostering international activity [55].

However, some studies revealed that the volume of FDI in a country tends to be inversely related to the weakness of IPR protection. Five studies looking at the FDI determinants of US Multinational Enterprises (MNEs) were found. The results show that the strength of IPR protection has a significant positive impact on the U.S. FDI [56]. For example, a one percent rise in the perceived weakness of IPR protection would decrease the U.S. FDI in that country by $14 \%$. In a sample of chemical firms, it was found that firms are likely to allocate their investment to sales and distributions and simple production activities rather than to manufacturing final products or to R\&D facilities [57]. This is confirmed in another study [58], in which it was suggested that a one percent rise in the extent of patent protection would increase the U.S. investment in that country by $0.45 \%$ [59].

Javorick (2004) indicated that weak protection of intellectual property rights deters foreign investors in four technology-intensive sectors: (1) drugs, cosmetics and health care products; (2) chemicals; (3) machinery and equipment; and (4) electrical equipment. In addition, foreign investors, in all industries, tend to set up distribution facilities rather than engaging in local production in a country with weak IPR protection [60]. Four studies confirmed that MNEs prefer investing in the regions that have better intellectual property rights protection [61-63]. For example, a one point increase in IPR index would boost FDI by $\$ 1.5$ billion [64].

Three studies using regression analysis yielded inconclusive results when analyzed in subgroups. Two studies showed the positive impact of strong national patent laws in developed countries, but showed a negative impact in developing countries $[65,66]$ while another study revealed the converse results [67].

In terms of the pharmaceutical industry specifically, a strong patent system was found to have caused a considerable flow of investment into the American pharmaceutical industry [68]. However, some studies show a negative correlation between the levels of protection and foreign investment. This is supported by conclusions elsewhere that the exclusion of pharmaceuticals from patent protection was a significant factor leading Italy to 


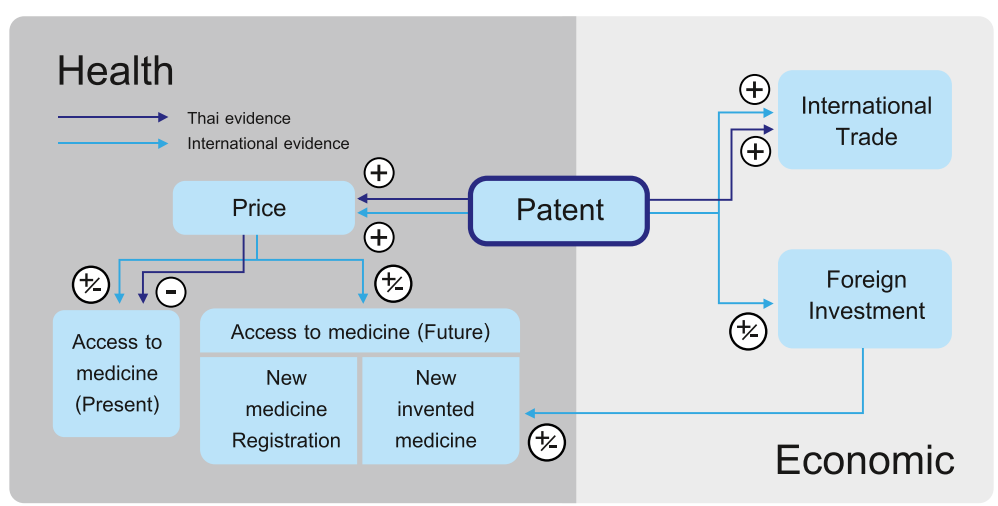

Figure 2 Availability of empirical evidence and direction of the relationship.

become a base for the export-oriented production of generic medicines [69]. Supakankunti (2001) showed that in Thailand there has been little foreign investment in the pharmaceutical sector since the introduction of the strengthened patent law in 1992 [70]. It has been suggested that this is because foreign investors consider Thailand an unsuitable destination due to the insufficiency of well-trained human resources, technology, and equipment, as well as the inadequacy of the registration system for new medicines [8] Table 6.

In conclusion, there are a number of empirical investigations pointing to an uncertain relationship between patent and FDI distribution, which depends on the political and business risks of the country included, FDI sources, data from opinion surveys or secondary data, and the approach used to calculate the level of patent protection scale. The question of just how important patent protection is for FDI is still unsettled. Some evidence indicates that patents have had a positive impact on FDI overall and the pharmaceutical industry in particular, while other evidence suggests that weak patent protection of pharmaceuticals was the main factor in making the country a manufacturing base for these pharmaceutical companies. As both countryspecific and regional factors influence the effect of patents on FDI, more regional and country-specific studies should be conducted in order to validate the findings of this study. As noted by Lesser (2002), the effect of IPR on FDI may only be possible on a countryby-country basis.

\section{Conclusions}

The empirical literature provides answers to some important questions related to the impact of patents, although evidence remains largely inconclusive. With respect to patent impact on price, both Thai and international evidence confirm that patenting shifts prices up and has an effect on the price of the new registration of medicines. In terms of present access, international empirical evidence demonstrates that patent protection does not always impede access, whereas a Thai study suggested that implementing a limited patent life may actually increase access. As for future access, evidence suggests that strengthening patent policy in a given nation may speed up the time required for entry into the pharmaceutical market. Empirical models estimate that higher profits, from patents, would increase the number of new medicines to market through higher R\&D budgets, enabling patients to benefit from access to new medicines in the future. Conversely, one observational study revealed that withdrawing exclusive rights by compulsory licensing might not have an effect on innovation in the future.

The evidence found from this review confirms that policy stimulating patent protection does have a positive impact on trade flows. In terms of FDI, evidence provides inconclusive results, both generally and specific to the pharmaceutical industry. Figure 2 summarizes existing evidence and the remaining gap, with an indication of the relationship found from this review.

The review revealed that little empirical research has been undertaken on the extent to which patent rights affect health and economic factors. With respect to health, the settings of the studies are very mixed across therapeutic areas and medicines. The literature generally shows that the size of impact varies wildly, depending on which methods are employed in the studies. Current evidence therefore makes it difficult for a country, such as Thailand, to come to a conclusion on advice to national policy makers who are to make decisions which trade off health or access impacts with wider economic issues. The high price of medicines may not be related to patent rights. Furthermore, price may not be related to access, either.

\section{Recommendations}

The trade-offs between patent protection, current and future access to medicines, and related aspects of trade 
and investment, are still subject to debate, since empirical studies are relatively rare, especially in countries such as Thailand. This underlines the urgent need to prioritize health research resources to assess the implications of patent protection.

It is clear that evidence on the role of patent/price on access, especially with respect to non-communicable diseases, is scare, inconclusive, and problematic. This suggests a more holistic assessment is required which takes into account a country's socio-economic status and health care system when estimating patent impact on access to medicine. The estimation of patent impact on technology transfer through FDI should be conducted on a country basis. In order to try and assess whether, on balance, a country is better off with patent policy related to health or not will require evaluating the implications for current and future access to medicines, and the wider national economy.

\section{Competing interest}

We declare that we have no competing interest.

\section{Authors' contributions}

IY designed the research methodologies and carried out the study. RD co-designed the methodologies, participated in discussions, and provided interpretations. The manuscript was written by IY and RS. All authors have contributed to, reviewed, and approved the final manuscript.

\section{Funding sources}

These findings are the result of work conducted during a WHO fellowship. The views expressed in this paper are those of the authors, and no official endorsement by the World Health Organization is intended or should be inferred.

\section{Acknowledgement}

We are grateful for the joint financial support to the Health Intervention and Technology Assessment Program (HITAP) by the Thai Health Promotion Foundation, Health System Research Institute, Bureau of Health Policy and Strategy, Ministry of Public Health, and the Thai Health-Global Link Initiative Project (TGLIP).

Received: 16 October 2011 Accepted: 3 July 2012

Published: 1 August 2012

\section{References}

1. Smith RD, Mackellar L: Global public goods and the global health agenda: problems, priorities and potential. Glob Heal 2007, 3(1):9.

2. Woodward D, Smith RD: Global Public Goods for health: concepts and issues. In Global Public Goods for health: a health economic and public health perspective. Edited by Smith RD, Beaglehole R, Woodward D, Drager N. Oxford: Oxford University Press; 2003.

3. Smith RD, Correa C, Oh C: Trade, TRIPS, and pharmaceuticals. Lancet 2009, 373(9664):684-691.

4. Thailand Overview. http://www.worldbank.org/en/country/thailand/overview.

5. Wibulpolprasert S: (Ed): Thailand Health Profile 2005-2007. Nonthaburi: Ministry of Public Health; 2007.

6. Sooksriwong C, Yoongthong W, Suwattanapreeda S, Chanjaruporn F: Medicine prices in Thailand: A result of no medicine pricing policy. Southern Med Review 2009, 2(2):10-14.

7. Ford N, Wilson D, Chaves GC, Lotrowska M, Kijtiwatchakul K: Sustaining access to antiretroviral therapy in the less-developed world: lessons from Brazil and Thailand. AIDS 2007, 21:S21-S29.

8. Kuanpoth J: Intellectual property rights and pharmaceuticals: a Thai perspective on prices and technological capability. Intellect Prop Q 2007,
2:186-215

9. Wang J-Y, Blomström M: Foreign investment and technology transfer: A simple model. Eur Econ Rev 1992, 36(1):137-155.

10. Borensztein $E$, De Gregorio J, Lee JW: How does foreign direct investment affect economic growth? J Int Econ 1998, 45(1):115-135.

11. Medecins Sans Frontieres: Untangling the web of price reductions: a pricing guide for the purchase of ARVs for developing countries. 9th edition. Geneva: Medecins Sans Frontieres; 2006.

12. Ministry of Public Health, National Health Security Office: Facts and evidences on the 10 burning issues related to the Government Use of patents on three patented essential drugs in Thailand. Nonthaburi: Ministry of Public Health, National Health Security Office; 2007.

13. Ministry of Public Health, National Health Security Office: The 10 burning questions regarding the Government Use of patents on the four anti-cancer drugs in Thailand. Nonthaburi: Ministry of Public Health, National Health Security Office; 2008

14. Special 301 Report. 2007. http://www.ustr.gov/about-us/press-office/reportsand-publications/archives/2007/2007-special-301-report.

15. U.S. Removes Certain Indian/Thai Jewellery from GSP Programme; Chinese Producers Poised to Take Advantage. http://info.hktdc.com/alert/us0715.htm.

16. Intellectual property: protection and enforcement. http://www.wto.org/ english/thewto_e/whatis_e/tif_e/agrm7_e.htm.

17. Watal J: Pharmaceutical patents, prices and welfare losses: Policy options for India under the WTO TRIPS agreement. World Economy 2000, 23(5):733.

18. Fink C: How stronger patent protection in India might affect the behavior of transnational pharmaceutical industries. Washington, DC: World Bank; 2000.

19. Boersma C, Klok RM, Bos JM, Naunton M, van den Berg PB, de Jong-van den Berg LTW, Postma MJ: Drug costs developments after patent expiry of Enalapril, Fluoxetine and Ranitidine: a study conducted for the Netherlands. Appl Health Econ Health Policy 2005, 4(3):191-196.

20. Suh DC, Manning WG Jr, Schondelmeyer S, Hadsall RS: Effect of multiplesource entry on price competition after patent expiration in the pharmaceutical industry. Health Serv Res 2000, 35(2):529-547.

21. Magazzini L, Pammolli F, Riccaboni M: Dynamic competition in pharmaceuticals: patent expiry, generic penetration, and industry structure. Eur J Health Econom 2004, 5(2):175-182.

22. Grabowski HG, Vernon JM: Brand loyalty, entry, and price competition in pharmaceuticals after the 1984 Drug Act. J Law Econ 1992, 35(2):331-350

23. Griliches Z, Cockburn I: Generics and new goods in pharmaceutical price indexes. Am Econ Rev 1994, 84:1213-1232.

24. Lu ZJ, Comanor WS: Strategic pricing of new pharmaceuticals. Rev Econ Stat 1998, 80(1):108-118

25. Kanavos PG, Vandoros S: Determinants of branded prescription medicine prices in OECD countries. Health Econ Policy Law 2011, 6(3):337-367.

26. Joan-Ramon B: Pricing and patents of HIV/AIDS drugs in developing countries. Appl Econ 2007, 39(4):505.

27. Supakankunti S: Janjaroen WS, Tangphao O, Ratanawijitrasin S, Kraipornsak P, Pradithavanij P: Study of the implications of the WTO TRIPS Agreement for the pharmaceutical industry in Thailand. New Delhi: WHO Regional Office for South-East Asia; 1999.

28. Limpananont L, Nilwatchararung D, Kulsomboon V, Maleewong U: Impact of U.S.Thailand FTA on access to medicine in Thailand. Bangkok: Social Pharmacy Research Unit, Faculty of Pharmcuetical Sciences, Chulalongkorn University; 2004

29. Jones JCH, Potashnik T, Zhang A: Patents, brand-generic competition and the pricing of ethical drugs in Canada: some empirical evidence from British Columbia, 1981-1994. Appl Econ 2001, 33(7):947-956.

30. Challu PM: Effects of the monopolistic patenting of medicine in Italy since 1978. Int J Technol Manag 1995, 10:237-250.

31. Akaleephan C, Wibulpolprasert S, Sakulbumrungsil R, Luangruangrong P, Jitraknathee A, Aeksaengsri A, Udomaksorn S, Tangcharoensathien V, Tantivess $S$ : Extension of market exclusivity and its impact on the accessibility to essential medicines, and drug expense in Thailand: analysis of the effect of TRIPs-Plus proposal. Health Policy 2009, 91(2):174-182

32. Yamabhai I, Mohara A, Krichanan W, Chaisiri K, Tantivess S, Teerawattananon Y: Assessing the implications of Thailand's Government Use Licenses, issued in 
2006-2008: Health Intervention and Technology Assessment Program; 2009.

33. Attaran A: How do patents and economic policies affect access to essential medicines in developing countries? Health Aff 2004, 23(3):155-166

34. Borrell JR, Watal J: Impact of patents on access to HIV/AIDS drugs in developing countries. Center for International Development at Harvard University. In Preliminary version; 2003.

35. Boehringer refuses to register Tipranavir in Brazil because of patent law. http:// www.aidsaccess.com/09/index.php? option=com content\&task=view\&id $=66 \&$ ltemid $=2$.

36. Doubts over Abbott's latest AIDS drug claim. http://eng.moph.go.th/ ContentDetails.php?intContent|D $=16014 \&$ strOrg|D=001002002

37. Mansfield E: Patents and innovation: an empirical study. Manag Sci 1986, 32(2):173-181.

38. Danzon PM, Wang YR, Wang L: The impact of price regulation on the launch delay of new drugs-evidence from twenty-five major markets in the 1990s. Health Econ 2005, 14(3):269-292.

39. Lanjouw JO: Patents, price controls, and access to new drugs: how policy affects global market entry: National Bureau of Economic Research; 2005.

40. Culpepper PD: Single Country Studies and Comparative Politics. Italian Politics \& Society 2005, 60:2-5.

41. NOGUÉS Jj: Social costs and benefits of introducing patent protection for pharmaceutical drugs in developing countries. Dev Econ 1993, 31(1):24-53.

42. Grootendorst P, Matteo LD: The effect of pharmaceutical patent term length on research and development and drug expenditures in Canada. Healthcare Policy 2007, 2(3):63-84.

43. Hughes JW, Moore MJ, Snyder EA: 'Napsterizing' pharmaceuticals: Access, innovation, and consumer welfare: National Bureau of Economic Research; 2002.

44. Giaccotto C, Santerre R, Vernon JA: Drug prices and research and development investment behavior in the pharmaceutical industry. I Law Econ 2005, 48(1):195-214.

45. Colleen C: Cheap drugs at what price to innovation: does the compulsory licensing of pharmaceuticals hurt innovation? Berkeley Technology Law Journal 2003, 18(3):853-908.

46. FTA Watch: Thailand's Free Trade Agreements and Human Rights Obligations. http://www.docstoc.com/docs/37091812/Thailands-Free-Trade-Agreementsnegotiations-and-Human-Rights.

47. Thailand Development Research Institute: A study on the impacts of Thailand-US Free Trade Agreement. Thailand-US Business Council (American Chamber of Commerce and the US-ASEAN Business Council); 2003.

48. Ferrantino MJ: The effect of intellectual property rights on international trade and investment. Rev World Econ 1993, 129(2):300-331.

49. Maskus KE, Penubarti M: How trade-related are intellectual property rights? J Int Econ 1995, 39(3-4):227-248.

50. Fink C, Braga CAP: Intellectual Property rights in a Gravity Model of International Trade Flows. In Policy research working Paper No 2051. The World Bank; 1999.

51. Pradhan JP: Strengthening intellectual property rights globally: impact on India's pharmaceutical exports. Singap Econ Rev 2007, 52(2):233-250.

52. Kondo EK: The effect of patent protection on foreign direct investment. Journal of World Trade 1995, 29(6):97-122.

53. Braga CP, Fink C: How stronger protection of intellectual property rights affects international trade flows. Washington, DC: World Bank; 1999

54. Pfister E, Deffains B: Patent protection, strategic FDI and location choices: empirical evidence from French subsidiaries' location choices in emerging economies. Int J Econ Bus 2005, 12(3):329-346.

55. Fosfuri A: Determinants of international activity: evidence from the chemical industry, CEPR Discussion Papers: 4601. 2004.

56. Nunnenkamp P, Spatz J: Intellectual property rights and foreign direct investment: a disaggregated analysis. Review of World Economics/ Weltwirtschaftliches Archiv 2004, 140(3):393-414.

57. Lee J-Y, Mansfield E: Intellectual property protection and U.S. foreign direct investment. Rev Econ Stat 1996, 78(2):181-186.

58. An $\mathrm{G}$, Maskus KE, Puttitanun T: Duration of rent extraction and the entry mode decision of multinational enterprises. Rev Dev Econ 2008, 12(4):861-876

59. Maskus KE: The international regulation of intellectual property. Review of World Economics (Weltwirtschaftliches Archiv) 1998, 134(2):186-208.
60. Javorcik BS: The composition of foreign direct investment and protection of intellectual property rights: evidence from transition economies. Eur Econ Rev 2004, 48:39-62.

61. Du J, Lu Y, Tao Z: Economic institutions and FDI location choice: evidence from US multinationals in China. J Comp Econ 2008, 36(3):412-429.

62. Kawai N: Location strategies of foreign investors in China: evidence from Japanese manufacturing multinationals. Glob Econ Rev 2009, 38(2):117-141.

63. Seyoum B: Patent protection and foreign direct investment. Thunderbird International Business Review 2006, 48(3):389-404

64. Lesser $W$ : The effects of intellectual property rights on foreign direct investment and imports into developing countries in the post TRIPs era. IP Strategy Today 2002, 5:1-15.

65. Park WG, Ginarte JC: Intellectual property rights and economic growth. Contemp Econ Policy 1997, 15(3):51-61.

66. Athukorala P-, Kohpaiboon A: multinational enterprises and globalization of R\&D: a study of U.S-based firms.: Australian National University, Economics RSPAS, Departmental Working Papers; 2006:38.

67. Blyde JS, Acea C: How does intellectual property affect foreign direct investment in Latin America? Integration and Trade 2003, 7(19):135-152.

68. Lehman B: The pharmaceutical industry and the patent system.: International Intellectual Property Institute; 2003.

69. Scherer FM, Weisburst S: Economic Effects of Strengthening Pharmaceutical Patent Protection in Italy. International Review of Industrial Property and Copyright Law 1995, 26:1009-1024.

70. Supakankunti S, Janjaroen WS, Tangphao O, Ratanawijitrasin S, Kraipornsak P, Pradithavanij P: Impact of the World Trade Organization TRIPS agreement on the pharmaceutical industry in Thailand. Bull World Health Organ 2001, 79(5):461-470.

doi:10.1186/1478-4505-10-24

Cite this article as: Yamabhai and Smith: A review of the health and economic implications of patent protection, with a specific focus on Thailand. Health Research Policy and Systems 2012 10:24.

\section{Submit your next manuscript to BioMed Central and take full advantage of:}

- Convenient online submission

- Thorough peer review

- No space constraints or color figure charges

- Immediate publication on acceptance

- Inclusion in PubMed, CAS, Scopus and Google Scholar

- Research which is freely available for redistribution 